\title{
Analysis of Classroom Teachers' Perceptions of Curriculum Literacy*
}

\author{
Fatih Selim Erdamar ${ }^{1}$, Burhan Akpunar ${ }^{2}$ \\ ${ }^{1}$ Frrat University, Institute of Educational Sciences, PhD Student, Elazig, Turkey \\ ${ }^{2}$ Firat University, Faculty of Education, Elazig, Turkey \\ Correspondence: Fatih Selim Erdamar, Frrat University, Institute of Educational Sciences, PhD Student, Elazig, Turkey
}

Received: November 11, 2019

Accepted: December 11, 2019 Online Published: January 2, 2020

doi:10.11114/jets.v8i3.4619

URL: https://doi.org/10.11114/jets.v8i3.4619

\begin{abstract}
The aim of this study is to analyze classroom teachers' perceptions of curriculum literacy according to various variables. The research based on screening model was conducted with 416 classroom teachers. The data were collected with the curriculum literary scale, which was valid and reliable. Data collected with four-dimensional scale were analyzed with descriptive statistical techniques. As a result of analyses, it was determined that literacy perceptions of the classroom teachers participating in the research were medium level in terms of sub-dimension of program elements. In this dimension, the highest perception is about measurement-evaluation and the lowest perception level is about the program perspective. In-service and post-graduate teachers have higher perceptions of literacy in the sub-dimension of curriculum elements. In the research, classroom teachers' perception of curriculum literacy is quite high in the sub-dimension of program implementation. Classroom teachers totally agree that parents, the internet, auxiliary resources, colleagues, textbook and school management support are respectively important in order to implement the curriculum; While female teachers find parental support more important in the implementation of the curriculum; the perceptions of teachers who are classroom teachers on internet support are more positive. In the sub-dimension of the program development and philosophy in the research, classroom teachers' perceptions of program philosophy in general are at medium level. Teachers receiving in-service training and those who are classroom teachers have higher perceptions of program philosophy. In this dimension, classroom teachers' perception of having knowledge about the epistemological bases of the program and the development stages of the program is low. Male teachers and teachers receiving in-service training have a higher perception of the development stages of the program. In this study, the perceptions of classroom teachers were moderate in the scale of program literacy training need. Perceptions of classroom teachers about their expectation from MoNE and their obligation to develop themselves are moderate.
\end{abstract}

Keywords: curriculum literacy, curriculum, classroom teachers, curriculum development

\section{Introduction}

Recently, quality issues and problems in Turkey have become increasingly more questionable. Quality in education is a multidimensional and complex issue. There are many variables that directly and indirectly affect quality in the education system and process. Among the variables that directly affect the quality of education; the characteristics of teacher and student, curriculum, management, technological and physical equipment are the first ones that come to mind. Quality in education is largely the product of the interaction between these variables. Although all of these variables are important, teacher quality and curriculum are critical. Dewey draws attention to the role of curriculum in raising the people of the modern world (Dewey, J., 1938). Indeed, the transformation of the educational policies of the state into practice is realized through education programs (Özdemir, 2009). Curriculum, which is one of the most important elements of formal education in the school, is the compass of the teaching process (Güzel and Karadağ, 2013). In this respect, the educational activities offered in the school can only reach their goals through curriculum (Çray, Küçükyllmaz and Güven, 2015: 32).

As briefly mentioned above, curriculum that has a direct or indirect relationship with all variables in the school are very important for quality in education. However, qualified teachers who will implement these programs effectively are just as important as that. Teachers' ability to implement the curriculum effectively depends to a large extent on their

${ }^{*}$ This study was produced from the doctoral thesis of the first author. 
knowledge and application skills. First of all, it is critical for teachers to know and understand the curriculum with all its dimensions and contexts. This is only possible if teachers have the knowledge and skills of curriculum literacy. Curriculum literacy is related to the beliefs, perceptions, knowledge and skills of teachers regarding the current curriculum, they teach in their classrooms. At the macro level, the achievement of a country's educational objectives depends on teachers' effective implementation of their curriculum; that is, their knowledge and skills in program literacy. At the micro level, teachers' ability to fulfill their expected pedagogical roles in the classroom depends on their program literacy qualifications.

Program literacy, albeit limited, exists in various forms in educational literature. According to Önal (2010) from various sources, program literacy can be defined as follows: teachers understand the program in all its dimensions, create contexts about it, apply the program effectively in the current conditions and contexts and obtain the expected results from the application. Bybee's (Bybee, R. W.1999) program literacy in the context of science literacy requires knowledge of the curriculum development process and context, meaning the program according to the current environment and conditions and implement it accordingly. As in general sense, literacy requires comprehension skills (Çoşkun, Cumaoğlu and Seçkin, 2013), analysis and prediction (Kurudayığlu and Tüzel, 2010; Sarıgöz, 2016). Accordingly, teachers' curriculum literacy qualifications require understanding and interpreting of curriculum in all its dimensions. In addition, it includes the teachers' interpretation of the program in terms of student, course content, school and community contexts. According to Akınoğlu and Doğan (2012), how teachers understand, how they perceive, their attitudes towards the curricula, and their skills and competencies to turn the programs into practice can be briefly called as curriculum literacy. Bolat (2017: 9) who conducted a detailed study on the subject, summarized the program literacy as having the knowledge of the basic components of the program; the objectives, content, learning-teaching processes and assessment and evaluation. Keskin and Korkmaz (2017, citied by Erdem, 2018) defined the program literacy as having information about the program, interpreting them, and critically examining them and adapting the curriculum to their conditions. Akınoğlu and Doğan (2012) emphasized that the most important condition for the realization of the education programs depends on the teachers' understanding of the structure, scope, relationship and characteristics of the programs and the planning of the things to be done to implement the program. It is also within the scope of curriculum literacy skills in which the knowledge and planning activities are done according to the characteristics and priorities of the school (Ornstein and Hunkins, 2017). In order to do this, it is important for teachers to interpret the existing environment and contextual situations rather than routine plans, and make appropriate planning (Nsibande, R. N. ve Modiba, M. M., 2012). On the other hand, Önal's (2010) definition of literacy skills means that teachers interpret and reflect their curriculum to the current situation. In this sense, curriculum literacy also refers to teachers' ability to combine theory and practice with the program. curriculum literacy is an important type of literacy that teachers and prospective teachers should acquire (Erdem and Eğmir, 2018). The teachers are expected to have knowledge of all the dimensions of the curriculums related to the course(s) they teach, and to design and implement the most effective applications to reach the program results from this knowledge. Based on all these definitions, program literacy can be defined as teachers' knowledge of all the components that make up the program.

In the context of the program literacy, the teacher should be able to select, organize and convert the content that is most suitable for the acquisitions, and apply them by transforming them into activities and finally to account for the achievement of the acquisitions. For this reason, it is important that teachers first understand the structure, scope, relationship and characteristics of the program and understand how the program can be performed (Gömleksiz and Erdem, 2018). On the one hand, it is important for teachers to have curriculum literacy qualifications not only for the quality of the existing education but also for the success of the reforms made in education. According to Akınoğlu and Doğan (2012), which moves the context further, curriculum literacy will shed light on the program development field, teacher competencies and evaluations to improve the quality of education. As a matter of fact, the relevant YOK (2018) documents draw attention to this case. In this study, we discussed classroom teachers program literacy perceptions based on opinions of teachers and conducted in a screening model.

\section{Method}

\subsection{Research Model, Universe and Sampling}

This research was conducted in a screening model. The screening model is a model based on a description and explanation of the current situation by taking samples from the universe (Karasar, 2016). The population of the study consists of primary school teachers working in public primary schools in Diyarbakır, Şırnak and Şanlıurfa provinces in 2018-2019 academic year / fall semester. The research sample consisted of 416 classroom teachers who voluntarily accepted to answer the related scale's items. Their distribution by province was as follows: Diyarbakır with 56 teachers (13.5\%); Şırnak with 37 teachers $(8.9 \%)$ and Şanlıurfa with 323 teachers (77.6\%). The demographic information of the sample is given in Table 1. 
Table 1. Demographic information of the teachers in sample group

\begin{tabular}{llll}
\hline Demographic Information & & $\mathbf{N}$ & $\mathbf{\%}$ \\
\hline Gender & Woman & 232 & 55.8 \\
\cline { 2 - 4 } & Man & 184 & 44.2 \\
\hline \multirow{2}{*}{ Branches } & Class & 397 & 95.4 \\
\cline { 2 - 4 } & Others & 19 & 4.6 \\
\hline \multirow{2}{*}{ Education Level } & Bachelor's degree & 380 & 91.3 \\
\cline { 2 - 4 } & Postgraduate & 36 & 8.7 \\
\hline \multirow{3}{*}{ Seniority } & $1-5$ years & 303 & 72.8 \\
\cline { 2 - 4 } & 6-10 years & 48 & 11.5 \\
\cline { 2 - 4 } & $11-15$ years & 28 & 6.7 \\
\cline { 2 - 4 } & $16-20$ years & 22 & 5.3 \\
\cline { 2 - 4 } Status of receiving in service training & 21 and more & 15 & 3.6 \\
\hline Total & Yes & 45 & 10.8 \\
\cline { 2 - 4 } & No & $\mathbf{4 1 6}$ & $\mathbf{1 0 0 . 0}$ \\
\hline
\end{tabular}

\subsection{Data and Analysis}

In this study, the data were obtained with the Teachers' Curriculum Literacy Perception Scale (TCLPS) developed by the researcher. The scale includes five personal information for teachers and 29 items for program literacy. These items are rated as "Totally Agree 5", "Agree 4", Undecided 3", "Disagree 2" and "Strongly Disagree 1". There are four sub-dimensions on the TCLPS. These dimensions are; program elements (15 items), program implementation (8 items), program development and philosophy ( 3 items), and program literacy training needs (3 items). After obtaining the necessary permissions by the researcher, the data collected was analyzed with descriptive statistical techniques. In the analyzes, $\mathrm{p}=.05$ was taken as the basis for significance level.

\section{Findings and Discussions}

\subsection{Teachers' Perceptions of Program Elements}

Table 2 shows the perceptions of the elementary school teachers who participated in the research regarding the Program Elements (PE) sub-dimension.

Table 2. Teachers' Perceptions of Program Elements

\begin{tabular}{llcc}
\hline It. & Teachers' Perceptions & $\overline{\mathrm{x}}$ & $\mathbf{S}$ \\
\hline 5 & I have sufficient knowledge of the program's student-centered nature. & 3.91 & .98 \\
6 & I have sufficient knowledge of the overall objectives of the current program. & 3.74 & .88 \\
7 & I have sufficient knowledge of the perspective of the current program. & 3.53 & .88 \\
8 & I have sufficient knowledge of the values highlighted in the current program. & 3.72 & .89 \\
9 & My knowledge of the teaching-learning approaches of the program is sufficient. & 3.77 & .85 \\
10 & I think I know the issues to be considered in the implementation of the program. & 3.66 & .86 \\
11 & My knowledge of the individual development feature highlighted in the program is sufficient. & 3.68 & .89 \\
12 & I have sufficient knowledge of the current program in general. & 3.80 & .87 \\
13 & I have sufficient knowledge of the acquisitions of my current program. & 3.86 & .88 \\
14 & I have sufficient knowledge of the content (unit-topics) of the program. & 3.85 & .85 \\
15 & I have sufficient knowledge of the activities of the current program I have implemented. & 3.81 & .86 \\
16 & I have sufficient knowledge about the assessment and evaluation approach of the program. & 3.78 & .86 \\
17 & I find myself adequate about the appropriate classroom management for the program. & 3.90 & .84 \\
18 & I find myself sufficient to make a program-based plan. & 3.81 & .86 \\
22 & I find myself competent in measuring and evaluating student achievement in accordance with & 3.93 & .83 \\
& the program understanding. & & \\
$\mathbf{T}$ & Program Elements Sub Dimension (Total) & $\mathbf{3 . 7 8}$ & $\mathbf{. 8 7}$ \\
\hline N=416 & &
\end{tabular}


When the data in Table 2 is analyzed in total firstly we can say there was no significant difference among the perceptions of teachers who participated in the study on the items in the PE sub-dimension according to gender, branch and seniority variables, it is understood that the perceptions of the class teachers participating in the research about the elements of the program they teach are at the level of "I agree" ( $\overline{\mathrm{x}}=3.78)$. When the data in Table 2 is analyzed on the basis of items, it can be stated that classroom teachers find themselves sufficient in terms of measurement-evaluation $(\bar{x}=3.93)$, student-centered feature of the program ( $\overline{\mathrm{x}}=3.91)$ and classroom management appropriate to the program $(\overline{\mathrm{x}}=3.90)$. The same teachers' perceptions of the program's perspective $(\overline{\mathrm{x}}=3.53)$, issues to be considered in the program $(\overline{\mathrm{x}}=3.66)$ and individual development characteristics $(\overline{\mathrm{x}}=3.68)$ were relatively lower. However, it can be said that the perceptions of teachers regarding all items in Table 2 are at the level of "agree" and the perceptions of the classroom teachers participating in the research regarding the current program are positive for PE dimension. Similarly, Özenç (2013) and Yeşilyurt and Yaraş (2011), in their studies, determined the level of alternative measurement and evaluation knowledge of classroom teachers and candidates to be at the medium level.

There was found a significant difference for the views of the $6^{\text {th }}$ item regarding the curriculum literacy according to the status of receiving in-service training (MWU $=6933.500 ; \mathrm{p}<.05)$. Accordingly, those who received in-service training $\left(\mathrm{MR}_{1}=239\right)$ in the relevant subject, perceived themselves to have more information about the general objectives of the program than those who did not $\left(\mathrm{MR}_{2}=204.69\right)$. There is a significant difference between the opinions of teachers regarding the $11^{\text {th }}$ item according to the education level $\left(\mathrm{t}_{414}=2.404 ; \mathrm{p}<.05\right)$. Accordingly, post-graduate classroom teachers $\left(\overline{\mathrm{x}}_{2}=3.71\right)$, are more self-sufficient in the program emphasized on the individual development characteristics compared to undergraduate graduates $\left(\overline{\mathrm{x}}_{1}=3.33\right)$.

\subsection{Teachers' Perceptions of Program Implementation}

Table 3 shows the perceptions of the classroom teachers about the sub-dimension of Program Implementation (PI).

Table 3. Teachers' Perceptions of Program Implementation

\begin{tabular}{llccc}
\hline It. & Teachers' Perception & $\overline{\mathbf{x}}$ & $\mathbf{S}$ \\
\hline 29 & $\begin{array}{l}\text { The support of parents of students is important for the effectiveness of the program } \\
\text { implementation. }\end{array}$ & 4.45 & .73 \\
30 & $\begin{array}{l}\text { The support of the textbook is important for the effectiveness of the program in } \\
\text { practice. }\end{array}$ & 4.20 & .86 \\
31 & $\begin{array}{l}\text { Helpful resources are important for the effectiveness of the program's } \\
\text { implementation. }\end{array}$ & 4.32 & .73 \\
32 & $\begin{array}{l}\text { Internet support is important for the effectiveness of the program in practice. } \\
33\end{array}$ & 4.37 & .76 \\
34 & $\begin{array}{l}\text { Textbook support is important for program-based planning (unit, daily). } \\
35\end{array}$ & $\begin{array}{l}\text { The support of my colleagues is important in making a program-based plan (unit, } \\
\text { daily). }\end{array}$ & 4.25 & .78 \\
36 & $\begin{array}{l}\text { The support of school administrators is important in making program-based plans } \\
\text { (units, daily). }\end{array}$ & 4.21 & .84 \\
$\mathbf{T}$ & Program Implementation Sub Dimension (Total) & $\mathbf{4 . 3 0}$ & $\mathbf{. 7 8}$ \\
\hline 16 & &
\end{tabular}

When the data given in Table 3 is analyzed in total, it is understood that the perceptions of the classroom teachers participating in the research in regard to the implementation of the current program is important is at the level of "I totally agree" $(\overline{\mathrm{x}}=4.30)$. This finding can be interpreted that the perceptions of classroom teachers about the importance of the mentioned variables on the implementation of the current program are highly positive. When the data in Table 3 is analyzed on the basis of items, it is observed that classroom teachers mostly care about parental support in the implementation of the current program $(\overline{\mathrm{x}}=4.45)$; this is followed by internet support $(\overline{\mathrm{x}}=4.37)$ and supplementary books. In similar studies, it was emphasized that the lack of sufficient information about the program in the implementation of primary school programs and the problems of the textbook make it difficult for the program to reach its purpose (Korkmaz, 2006).

Family support is important in the implementation of the program, as children are first learning from their parents' feedback (Bricklin, P. M., 1991). In addition, the fact that the Internet has a critical importance in accessing and sharing information in the information age (Akkoyunlu, 2002: 1) makes teachers' perceptions about internet support meaningful. 
However, most of the school computers do not have internet connection (Gelen \& Beyazit, 2007). As a matter of fact, Karacaoğlu and Acar (2010) emphasized the problems related to the use of equipment among the problems encountered in the implementation of the programs.

While there was no significant difference between the perceptions of the teachers participating in the study on the items in the PI sub-dimension according to the level of education, receiving status of in-service training and seniority variables, there was found a significant difference between the views of $29^{\text {th }}$ and $32^{\text {nd }}$ items according to gender $\left(t_{414}=2,283 ; p<.05\right)$; $\left(\mathrm{t}_{414}=2.845 ; \mathrm{p}<.05\right)$. Accordingly, female teachers $\left(\overline{\mathrm{x}}_{1}=4.52\right)$ find parental support more important in the implementation of the program than men $\left(\overline{\mathrm{x}}_{2}=4.35\right)$. Similarly, female teachers $\left(\overline{\mathrm{x}}_{1}=4.46\right)$ find internet support more important than male $\left(\overline{\mathrm{x}}_{2}=4.25\right)$ in terms of the effectiveness of the program in practice.

There is a significant difference between teachers' opinions regarding the $32^{\text {nd }}, 33^{\text {rd }}$ and $34^{\text {th }}$ items in Table 3 $\left[\left(\mathrm{t}_{32-414}=2.489 ; \mathrm{p}<.05\right) ;\left(\mathrm{t}_{33-414}=2.348 ; \mathrm{p}<.05\right) ;\left(\mathrm{t}_{34-414}=2.165 ; \mathrm{p}<.05\right)\right]$. According to this, the teachers who are class teachers $\left(\overline{\mathrm{x}}_{1}=4.38\right)$ consider internet support more important than the other branch teachers $\left(\overline{\mathrm{x}}_{2}=4.38\right)$ in terms of the effectiveness of the program. Similarly, teachers who are class teachers $\left(\overline{\mathrm{x}}_{1}=4.25\right)$ consider the textbook support more important than the other branch teachers $\left(\overline{\mathrm{x}}_{2}=3.84\right)$. In the same parallel, the teachers who have branch teachers $\left(\overline{\mathrm{x}}_{1}=4.35\right)$ consider internet support more important than the other branch $\left(\overline{\mathrm{x}}_{2}=3.95\right)$.

\subsection{Teachers' Perceptions of Program Development and Philosophy}

Table 4 shows the perceptions of the classroom teachers involved in the research regarding the sub-dimension of Program Development and Philosophy (PDP).

Table 4. Teachers' Perceptions of Program Development and Philosophy

\begin{tabular}{llcc}
\hline It. & Teachers' Perceptions & $\overline{\mathrm{x}}$ & $\mathrm{s}$ \\
\hline 1 & I have sufficient knowledge of the development of the current program & 3.15 & .97 \\
2 & I have sufficient knowledge of the philosophy of education on which the current & 3.58 & .90 \\
& program is based & & \\
3 & I have sufficient knowledge of the epistemological foundations of the program & 3.38 & .90 \\
$\mathbf{T}$ & Program Development and Philosophy Sub-Dimension (Total) & $\mathbf{3 . 3 7}$ & $\mathbf{. 9 2}$ \\
\hline
\end{tabular}

$\mathrm{N}=416$

There is a close relationship between teachers' attitudes, perceptions, and consequently their instructional behaviors towards the curriculum they teach, and the philosophy on which the curriculum is based. As a matter of fact, research shows that there is a significant positive relationship between teachers' philosophy of educational beliefs and their teaching-learning understanding (Baş, 2015: 111). Although the participants agree on items about the philosophy of the program $(\bar{x}=3.58)$; it is understood that their perceptions about the epistemological bases of the program $(\bar{x}=3.38)$ and having information about the development stages of the program $(\overline{\mathrm{x}}=3.15)$ are partially in agreement. This finding can be interpreted as the classroom teachers who participated in the research did not know the epistemological dimension of the program they taught. This is an important deficiency due to the fact that epistemology is a dynamic area (Demir and Akınoğlu, 2010) which can both affect the education field and can be affected by the education process. In their research, Ekinci and Tican (2017) found that the epistemological beliefs of classroom teachers were important predictors of classroom practices. It is also an important shortcoming that classroom teachers are partially aware of the development stages of the program. Because the development process is a stage that gives important information about the curriculum.

While there was no significant difference between the perceptions of teachers who participated in the study on items in the PDP sub-dimension according to the branch, education level and seniority variables, there was found a significant difference between the views on the first item by gender $\left(\mathrm{t}_{1-414}=-2.878 ; \mathrm{p}<.05\right)$. Accordingly, male teachers $\left(\mathrm{x}_{2}=3.30\right)$, women $\left(\bar{x}_{1}=3.02\right)$ have higher perceptions of finding themselves more competent about the development stages of the program. There is a significant difference between the perceptions of teachers regarding items 1,2 and 3 according to the status of receiving in-service training [( $\left.\left.\mathrm{t}_{1-414}=5.276 ; \mathrm{p}<.05\right) ;(\mathrm{MWU}=6287.500 ; \mathrm{p}<.05) ;(\mathrm{MWU}=5499.000 ; \mathrm{p}<.05)\right]$. According to this, classroom teachers $\left(\overline{\mathrm{x}}_{1}=3.84\right)$ who receive in service trainings find themselves more knowledgeable about the development stages of the current program than those who do not $\left(\overline{\mathrm{x}}_{2}=3.84\right)$. Again, the teachers who receive in service trainings $\left(\mathrm{MR}_{1}=254.28\right)$ find themselves more adequate about the philosophy of the program than those who do not $\left(\mathrm{MR}_{2}=202.95\right)$, Similarly, classroom teachers who received in service trainings $\left(\mathrm{MR}_{1}=271.80\right)$ find themselves more competent about the epistemological basis of the program than those who did not $\left(\mathrm{MR}_{2}=200.82\right)$. It can be interpreted that this training is beneficial as the classroom teachers who take in service trainings have more positive perceptions about program philosophy and epistemological bases. As a matter of fact, Özen (2006) in his study, found that elementary school teachers found in service trainings useful. 


\subsection{Teachers' Program Literacy Training Needs}

Table 5 shows the perceptions of the class teachers who participated in the study on the need for program literacy education (PLTN).

Table 5. Teachers' Perceptions of Program Literacy Training Needs

\begin{tabular}{clcc}
\hline It. & Teacher Perceptions & $\overline{\mathbf{x}}$ & $\mathbf{s}$ \\
\hline 37 & I need training in program literacy & 3.92 & .89 \\
38 & Education about program literacy should be provided by MoNE & 4.07 & .93 \\
40 & Every teacher is obliged to improve himself / herself in terms of program literacy & 3.87 & .96 \\
$\mathbf{T}$ & Program Literacy Training Needs Sub-Dimension (Total) & $\mathbf{3 . 9 5}$ & $\mathbf{. 9 3}$ \\
\hline 16 & & &
\end{tabular}

When the items in Table 5 are considered as a total, it is seen that the perceptions of the teachers who participated in the research were at the level of "I agree" for the dimension of PLTN. When the items were analyzed one by one, it can be stated that classroom teachers had the perception of program literacy training need $(\bar{x}=3.92)$, had expectations from MoNE ( $\overline{\mathrm{x}}=4.07)$, they perceived themselves to be responsible as well $(\overline{\mathrm{x}}=3.87)$. Teachers' perception of program literacy training need is an important finding showing their awareness on the subject. Because program literacy which is related to the recognition and understanding of the program they teach (Önal, 2010), is very important in terms of the effectiveness of the teaching process. The most important condition for the implementation of the curriculum in accordance with the nature of the program is that teachers know the structure, scope, relationship and characteristics (Erdem and Eğmir, 2018). Thus, the gap between program theory and practice (Ornstein and Hunkins, 2017), which is often the problem, is also reduced.

The expectation of teachers from the MoNE on this subject may be related to the education culture in our country. In Turkey, renewal of the teachers themselves are not left to individual efforts with the National Education Basic Law regulated by Law No. 657 (Günba and Taşdöğen, 2012). The perception that teachers have obligations in this regard may be related to the fact that teachers have become more involved in the development of educational programs in recent years (Wiles, 2009) and their responsibility awareness. However, since it is known that many problems are present for in service trainings carried out in Turkey, it should be on a voluntary basis and through distance education / in service training (Parmaksiz and Sicak, 2015) as an alternative.

There was no significant difference between the perceptions of the teachers who participated in the study on the items in the PLTN according to the variables such as gender, branch, education level, inservice status and seniority variables.

\section{Result}

There is no doubt that qualified teachers are needed for qualified education (Darling-Hammond, 2000; Arslan \& Özpınar, 2008; Seferoğlu, 2004). Teacher quality is a critical variable affecting student achievement, which is one of the important indicators of qualified education (Caena, 2011; Sass et al., 2012; Adesina et al., 2016; Demirtaş, 1999). Teacher quality is a very complex issue in terms of scope. The epistemological and pedagogical beliefs and attitudes of the teacher, general culture and field knowledge and knowledge and skills of program literacy are among the first ones that come to mind. Of these, program literacy is closely related to quality in education. This is because the ability of teachers to implement programs effectively in order to achieve the goal in formal education depends to a large extent on the knowledge and skills of program literacy.

The general perceptions of the primary school teachers who participated in the research on the program elements, the first sub-dimension of the scale, were moderate. Although this level is not too high, it can be considered that teachers have a positive attitude towards the current program, which is important for quality in education Anagün, Atalay and Kılıç (2016) stated that classroom teachers' perspectives on measurement and evaluation approaches were positive. However, in other related studies, it has been shown that classroom teachers have problems in process-oriented assessment (Özenç, Doğan \& Çakır, 2017) and that they do not have enough information about this subject (Anıl and Acar, 2008).

Due to the harmony between the educational theory programs and the teaching process, which means educational practice, depends to a great extent on the correct implementation of the program by the teachers. This depends to a great extent on the positive attitude and perception of the teachers towards the relevant program. Contrary to the literature, the highest perception of the classroom teachers in this sub-dimension is directed towards the measurement and evaluation element of the program. The process-oriented measurement-evaluation subject is learned over the time, which was previously seen as a serious problem (Güneş, 2007; Kilmen and Demirtaşl1, 2009; Gök and Şahin, 2009). 
By virtue of the existing programs foreseeing process and result based measurement and evaluation have been in practice for nearly 20 years. In the sub-dimension of program elements, teachers' lowest perception is about the perspective of the current program. This may be due to the lack of knowledge of the teachers about the philosophical basis of the program or the lack of a clear perspective on the current program.

In the sub-dimension of the program elements, the classroom teachers who received in service trainings on the subject were compared to those who did not; the perception of program literacy was found to be higher among the postgraduate teachers than the undergraduate graduates. Accordingly, it can be concluded that in service trainings and postgraduate education positively affect classroom teachers' perception of program literacy. As a matter of fact, well-constructed studies conducted by experts showing the positive effects of in-service trainings (Garet, M.S., et all 2001) support this conclusion. Therefore, developed countries attach great importance to in-service training of teachers (Erdem \& Şimşek, 2013; 96). Similarly, the postgraduate education which provides the methods and skills of specialization, knowledge generation and synthesis in professional fields (Karaman and Bakırc1, 2010: 95) explains the reasons behind the higher level of postgraduate teachers' perception of program literacy.

In the sub-dimension of the program implementation, classroom teachers' perceptions are high for support for parents, the internet, auxiliary resources, colleagues, textbooks and school management (at the level of I totally agree). Accordingly, it can be concluded that classroom teachers have the perception that the support of parents, internet, auxiliary resources, colleagues, textbooks and school management are the most important in the implementation of the primary school curriculum. As a matter of fact, it is vital that the family (Genç, 2006: 1), the oldest, most permanent, safest and most natural social institution of the society supports the implementation of the program that regulates the instructional functioning in the school institution. The family is a non-formal education institution and the education of the individual starts first in the family and continues in the schools which are formal education institutions (Yapic1, 2010: 1545). In this sub-dimension, female class teachers find parental support more important in the implementation of the program as women are more sensitive to the family.

Positive teacher perceptions of internet support in the implementation of the program are quite meaningful today as it is the Information Age. The internet provides teachers with the opportunity to communicate with their colleagues or interested people, institutions and organizations both in our country and around the world. Thus, while the quality of education increases, the teacher also has the opportunity to refresh their knowledge (Bakioğlu and Şentuna, 2001). In the sub-dimension of the implementation of the program, the perceptions of female class teachers and teachers whose branches are class are more positive in terms of internet support in the implementation of the program.

The positive perceptions of classroom teachers towards the support of supplementary resources such as textbooks in the implementation of the program are understandable when considering the support of supplementary resources such as textbooks in the pre-class preparation and planning studies (Göçer and Aktürk, 2015: 188). In relation to this, the perceptions of the class teachers in the implementation of the program towards internet support are more positive. Considering the fact that the teachers benefit from their colleagues in preparing the plans in the teaching process regarding the implementation of the program (Köksal, 2008), positive teachers' perceptions towards this are understandable. In the research, the support for classroom teachers in the implementation of the program are consistent with the literature.

One of the first steps to be taken in initiatives to improve the quality of education should be to understand the values and beliefs of teachers (Carter and Norwood, 1997). It is known that epistemological beliefs and philosophical positions of teachers have a serious effect on their teaching practices (Tunca, Alkın-Şahin and Oğuz, 2015). In this respect, it is important for the teachers to know the philosophical approaches on which the programs are taught and have knowledge about the development process of the program. In the research, classroom teachers' perceptions about program philosophy in general were moderate (I agree) in the sub-dimension of program development and philosophy; their perceptions of the knowledge about the epistemological bases of the program and the development stages of the program are low (I partly agree). In this sub-dimension, teachers receiving in service trainings and teachers whose branch is class teaching have higher perceptions of knowing the philosophical basis of the program. Male teachers and teachers receiving in service trainings have a higher perception of knowing the development stages of the program.

It is contradictory for teachers to know the program philosophy in general and to know the epistemological bases and development process in part. This contradiction may be related to the fact that teachers do not have full command of program philosophy or cannot reflect this philosophy to the teaching process. Saydam (2009), Karadağ, Deniz, Korkmaz and Deniz (2008) found that although primary school teachers' perceptions of program philosophy were positive, they could partially implement it. As a matter of fact, due to this philosophical deficiency, the Council of Higher Education (YOK) added "philosophy of education" to the teacher training programs in 2018. The insufficient knowledge of the classroom teachers involved in the research on the epistemological basis of the program and the 
development process can be considered as a serious deficiency in terms of the effectiveness of the teaching process. Teachers should have a clear perspective about the philosophy that constitutes the infrastructure of educational practices (Kottalil, 2009).

In the study, in the sub-dimension of educational training need, the perceptions of classroom teachers about the need for education are moderate (I agree). Accordingly, it was concluded that classroom teachers needed training on the subject and had expectations from MoNE for this training and that they felt themselves as responsible. This situation is positive in terms of the quality of education at the macro level and the quality of teachers at the micro level. The main determinant role in education and training process, including quality are based on programs themselves (Ulutaş and Erman, 148). Indeed, the World Bank (2005) report on the issue of quality in primary education in Turkey, associated with the old curriculum and the justification for the new curriculum is based on old curriculum' shortcomings (Gur and Steel, 2009: 19). Therefore, as the knowledge and skills of program-literacy increase the effectiveness of existing programs, the quality of the teaching process will be positively affected. Teachers' responsibility to develop themselves on the subject is critical in our age when human quality is accepted as a determining factor in all areas (Gelen and Beyazit, 2007: 459). This sensitivity of teachers can be evaluated within the scope of vocational learning rather than professional development (Tofur, 2015: 19).

\section{Conclusion}

In this study, we discussed classroom teachers program literacy perceptions in terms of sub- dimension program elements. It was concluded that MoNE should organize trainings and activities to increase the awareness of teachers about program literacy and support their knowledge.

However, it is important that these trainings and activities are carried out with a holistic approach, including an understanding of general culture, field knowledge and educational science. In conclusion, the study can be expected to highlight the importance of the quality in education and contribute to the literature.

\section{References}

Adesina, O. J., Raimi, S. O., Bolaji, O. A., \& Adesina, A. E. (2016). Teachers' Attitude, Years of Teaching Experience and Self-Efficacy as Determinants of Teachers' Productivity in Teachers' Professional Development Program in Ibadan Metropolis, Oyo State, Nigeria. Journal of Emerging Trends in Educational Research and Policy Studies, 7(3), 204-211.

Akınoğlu, O., \& Doğan, S. (2012). A new Concept of Program Development in Education Recommendation: Program Literacy, $21^{\text {st }}$.National Educational Science Congress, İstanbul, 12-14, September, 2012.

Akkoyunlu, B. (2002). Use of Internet by Teachers and Their Opinions on the Issue, Hacettepe University Journal of Education, 22, 1-8.

Anıl, D., \& Acar, M. (2008). Elementary School Teachers' Views On Issues They Experience Through Measurement And Evaluation Processes, Yüzüncü Yll University Journal of Education, V(II), 44-61.

Anılan, H., Anagün, Ş. S., Atalay, N., \& Kılıç, Z. (2016). Classroom Teachers Views About Measurement And Evaluation Approaches Based On Learning Process, Journal of Research in Education and Teaching, 5, 200-211.

Arslan, S., \& Özpınar, İ. (2008). Teachers Qualifications: Comparison Between Primary School Curriculum Expectations And Teachers Acquisitions In Education Faculties, Necatibey Faculty of Education Electronic Journal of Science and Mathematics Education, 2(1), 38-63.

Bakioğlu, A., \& Şentuna, T. (2001). Teachers and School Managers in Education with Internet Tasks, Pamukkale University Journal of Education, 9, 10-18.

Baş, G. (2015). Correlation Between Teachers' Philosophy of Education Beliefs and Their Teaching-Learning Conceptions, Education and Science, 40(182), 111-126. https://doi.org/10.15390/EB.2015.4811

Bolat, Y. (2017). Concept of Curriculum Literacy and Curriculum Literacy Scale. Turkish Studies, 12(18), 121-138. https://doi.org/10.7827/TurkishStudies.12103

Bricklin, P. M. (1991). The concept of "self as learner": Its critical role in the diagnosis and treatment of children with learning disabilities, International Journal of Reading Writing and Learning Disabilities, 7(3), 201-217. https://doi.org/10.1080/0748763910070304

Bybee, R. W. (1999). Toward An Understanding Of Scientific Literacy,(In Advancing Standards for Science and Mathematics Education :Views From the Field ,The American Association for the Advancement of Science, Washington, DC. (Adapted from Bybee, R. W. 1997. Achieving Scientific Literacy: From purposes to practices. Portsmouth, NH: Heinemann Publishing). 
Caena, F. (2011). Literature Review Quality in Teachers' Continuing Professional Development. Education and Training, 2020, 2-20. Downloaded from https://pdfs.semanticscholar.org/ on 15.07.2017

Carter, G., \& Karen, S. N. (1997). The Relationship between Teacher and Student Beliefs about Mathematics, School Science and Mathematics, 97(2), 62-67. https://doi.org/10.1111/j.1949-8594.1997.tb17344.x

Çıray, F., Küçükyılmaz, E. A., \& Güven, M. (2015). The Views of Teachers about the Curriculum of Science Revised for Secondary Schools, Dicle University Journal of Ziya Gökalp Faculty of Education, 25, 31-56. https://doi.org/10.14582/DUZGEF.566

Coşkun, Y. D., Cumaoğlu, G. K., \& Seçkin, H. (2013). Computer Technology Teacher Candidates’ Views On The Concepts Of Literacy Related To Information Technology. International Journal of Human Sciences, 10(1), 1259-1272.

Darling-Hammond, L. (2000). Teacher Quality and Student Achievement. Education Policy Analysis Archives, 8(1), 1-44. https://doi.org/10.14507/epaa.v8n1.2000

Demir, S., \& Akınoğlu, O. (2010). Epistemological Beliefs in Teaching Learning Processes, Atatürk Education Faculty Journal of Educational Science, 32, 75-93.

Demirtaş, H. (1999).Teacher Beahaviours in Classroom, Teacher World, 20(238), 32-35.

Dewey, J. (1938). Experience and education. New York: Macmillan.

Ekinci, N., \& Tican, C. (2017). Classroom Teachers' Epistemological Beliefs and Their Classroom Practices for Teaching Thinking Skills. Journal of Human and Journal Sciences Research, 6(3), 1747-1773.

Erdem, A. R., \& Şimşek, S. (2013). Investigating In-Service Training Given to Teachers and School Heads, Uşak University Journal of Social Sciences, 6(4), 94-108.

Erdem, C. (2018). Prospective Teachers Levels of Education Program Literacy. 8th International Congress of Research in Education (ULEAD 2018), Manisa.

Erdem, C., \& Eğmir, E. (2018). Prospective Teachers' Levels of Curriculum Literacy, Afyon Kocatepe University Journal of Social Sciences, 20(2), 123-138. https://doi.org/10.32709/akusosbil.428727

Garet, M. S., Porter, A. C., Desimone, L., Birman, B. F., \& Yoon, K. S. (2001). What makes professional development effective? Results from a national sample of teachers, American Educational Research Journal, 38(4), 915-945. https://doi.org/10.3102/00028312038004915

Gelen, İ., \& Beyazit, N. (2007). Comparing Perceptions of the New Primary School Curriculum with the Former Curriculum, Educational Administration: Theory and Practice, 51, 457-476.

Genç, S. Z. (2006). Family School and Society in Education Process, Pegem Academy, Ankara

Göçer, A., \& Aktürk, Y. (2015). Perceptions of Primary and Secondary School Teachers on Teacher's Guidebooks: A Metaphor Analysis, International Journal of Turkish Education Sciences, April, 186-199.

Gök, B., \& Şahin, A. E. (2009). The Multiple Uses of Assessment Methods in 4th and 5th Grades and the Competency Levels of Teachers, Education and Science, 34(153), 127-143.

Gömleksiz, M. N., \& Erdem, Ş. (2018). Perceptıons Of Prospectıve Teachers Enrolled At Education Faculty And Pedagogical Formation Course Towards Curriculum Literacy, The Journal of Academic Social Science Studies, 73, 509-529.

Günbayı, İ., \& Taşdöğen, B. (2012). Compulsory School Teachers' Views On In-Service Education Programs: A Case Study, Journal of the Human and Social Science Researches, 1(3), 87-117.

Güneş, A. (2007). Measurement and Evaluation Competencies of Classroom Teachers According to Their Perceptions, Unpublished Master Degree, Marmara University Institute of Educational Sciences, İstanbul.

Gür, B., \& Çelik, Z. (2009). National Education System in Turkey Structural Issues and Recommendations. SETA Report, October, 2009

Güzel, A., \& Karadağ, Ö. (2013). A Critical Look at Turkish Curriculum (6, 7 and 8th Grades) in Accordance with Explanation Abilities, Journal of Mother Tongue Education, 1(1), 45-52.

Karacaoğlu, Ö. C., \& Acar, E. (2010). The Issues That Teachers Encounter During Application Of New Curricula, Yüzüncü Yll University Journal of Education, VII(I), 45-58.

Karadağ, E., Deniz, S., Korkmaz, T., \& Deniz, G. (2008). Constructivist Learning Approach: A Research within the Scope of Classroom Teachers' Opinions, Uludağ University Journal of Education, XXI(2), 383-402. 
Karaman, S., \& Bakırc1, F. (2010). Postgraduate Study in Turkey: Problems and Proposed Solutions, Journal of Social Sciences Research, II, 94-114.

Karasar, N. (2016). Scientific Research Method, Ankara: Nobel Publication.

Kilmen, S., \& Demirtaşl1, Ç. N. (2009). The Perceptions of Primary School Teachers About Their Application Levels of Measurement and Evaluation Principles, Ankara University Journal of Faculty of Educational Sciences, 42(2), 27-54.

Köksal, N. (2008). Assessment of Generic Competences of Teaching Profession by Teacher, School Director and Consultants from the Ministry of National Education, Pamukkale University Journal of Education Faculty, 1(23), $36-46$.

Korkmaz, İ. (2006). The Evaluation of New Primary School First Grade Program by Teachers", Gazi University Education Faculty National Classroom Teacher Congress Book. Ankara: KökPublishing.

Kottalil, N. K. (2009). Meaning making and self-evaluation, ERIC database, (30.05.2009)

Kurudayığlu, M., \& Tüzel, S. (2010). The Types of Literacy of the 21st Century, Changing Text Comprehension and Turkish Teaching, TÜBAR, XXVIII, 283-298.

Nsibande, R. N., \& Modiba, M. M. (2012). "I Just Do As Expected'. Teachers implementation of Continuous Assessment and Challenges to Curriculum Literacy", Research Papers in Education, 27(5), 629-645. https://doi.org/10.1080/02671522.2011.560961

Önal, İ. (2010). Lifelong Learning and Literacy in Process of Historical Change: A Turkish Experience, Information World, 11(1), 101-121.

Ornstein, A. C., \& Hunkins, F. P. (2017). Curriculum-Foundations, Principles, and Issues Global Edition, Pearson Education Limited.

Özdemir, S. M. (2009). Curriculum Evaluation In Education And Examination Of The Curriculum Evaluation Studies In Turkey, Yüzüncü Yll University Journal of Education Faculty, VI(II), 126-149.

Özen, R. (2006). Perceptions of Primary School Teachers About the Effects of Inservice Training (INSET) Programs (A Case Study: Düzce), Abant İzet Baysal University Journal of Education Faculty, 6(2), 141-160.

Özenç, M. (2013). Determination of Levels of Primary School Teachers' Alternative Assessment and Evaluation Knowledge, Dicle University Journal of Ziya Gökalp Faculty of Education, 21, 157-178.

Özenç, M., Doğan, C., \& Çakır, M. (2017). Determining Primary School Teachers' Perspectives of Alternative Assessment and Evaluation, Dicle University Journal of Ziya Gökalp Faculty of Education, 30, 588-607. https://doi.org/10.14582/DUZGEF.1816

Parmaksız, R. Ş., \& Sicak, A. (2015). Opinions of Teacher's About the In- Service Training, Uşak University Journal of Social Sciences, 8(4), 187-212.

Sarıgöz, O. (2016). Anthropological Attitudes and Views of the Teachers Towards Lifelong Learning, The Anthropologist, 24(2), 598-610. https://doi.org/10.1080/09720073.2016.11892054

Sass, T. R., Hannaway, J., Xu, Z., Figlio, D. N., \& Feng, L. (2012). Value Added of Teachers in High-Poverty Schools and Lower Poverty Schools, Journal of Urban Economics, 72(2-3), 104-122. https://doi.org/10.1016/j.jue.2012.04.004

Saydam, G. (2009). Elementary Teachers' Views And Attitudes Towards Applying Constructivist Approach In Education, Adnan Menderes University Institute of Social Sciences.

Seferoğlu, S. S. (2004). Teacher competencies and professional development .Education in the Brightness of Science and Reason, 58, 40-45.

Tofur, S. (2015). Evaluation of 21. Century Turkish Education Policy Documents Based on Fullan's Conceptualizations: 1980-2014, PhD Thesis, Eskişehir Osmangazi University Instıtute of Educational Sciences.

Tunca, N., Alkın-Şahin, S., \& Oğuz, A. (2015). The Relationship Between Teachers' Educational Beliefs and Professional Values, Kalem Journal of Education and Human Sciences, 5(1), 11-47. https://doi.org/10.23863/kalem.2017.43

Ulutaş, S., \& Erman, M. (2011). Since The Foundation Of The Republic Implemented In Turkey With Elementary Middle School An Primary School Curriculum Assessment and Evaluation, Journal Of Measurement and Evaluation in Education and Psychology, 2(1), 148-154.

Wiles, J. (2009). Leading Curriculum Development, Corwin Press. 
Yapıcı, Ş. (2010). Relationship Between Family and Education in Turkish Society, Turkish Studies, 4(5), 1544-1570. https://doi.org/10.7827/TurkishStudies.1495

Yeşilyurt, E., \& Yaraş, Z. (2011). Assessment of Classroom Teacher Candidates' Perception of Knowledge Level about Measurement and Evaluation Methods, Ahi Evran University Journal of Kırşehir Education Faculty, 12(4), 95-118.

YÖK (2018). Turkey Higher Education Council, Ankara.

\section{Copyrights}

Copyright for this article is retained by the author(s), with first publication rights granted to the journal.

This is an open-access article distributed under the terms and conditions of the Creative Commons Attribution license which permits unrestricted use, distribution, and reproduction in any medium, provided the original work is properly cited. 